\title{
The role of the family doctor in the early diagnosis of colorectal cancer
}

\author{
Rolul medicului de familie în diagnosticul precoce al cancerului colorectal \\ Mihaela Adela IANCU ${ }^{1,2}$, Gabriela GANEA ${ }^{3}$, Ramona Dorotea CĂLIN ${ }^{1,2}$, Irina Anca EREMIA ${ }^{1,4}$, \\ Adriana TICĂRĂU ${ }^{1,2}$, Camelia Cristina DIACONU ${ }^{1,5}$, Dumitru MATEI ${ }^{1,6}$ \\ ${ }^{1}$ Universitatea de Medicină și Farmacie „Carol Davila“, București, România \\ ${ }^{2}$ Cabinet medical individual, București, România \\ ${ }^{3}$ Spitalul Clinic de Urgență pentru Copii „MS Curie“, București, România \\ ${ }^{4}$ Spitalul Universitar de Urgență, București, România \\ ${ }^{5}$ Spitalul Clinic de Urgență, București, România \\ ${ }^{6}$ Institutul Național pentru Sănătatea Mamei și Copilului „Alessandrescu-Rusescu“, București, România
}

\begin{abstract}
The incidence of colorectal cancer is increasing. It is currently the third most common cancer, after lung and breast cancer. Despite the increased incidence, recent advances in early detection, performing the screening according to the recommendations and treatment options have reduced colorectal cancer mortality. The role of the family doctor is to advise and to identify non-modifiable risk factors (age, male sex, race, family history, inflammatory bowel disease) as well as modifiable ones (tobacco consumption, low-fiber, high-fat and highcarbohydrate diet, a sedentary lifestyle, obesity), in order to avoid these risk factors by developing a personalized plan for the prevention and early detection of colorectal cancer depending on the individual risk. Genetic testing and a more comprehensive family history documentation by the family doctor can enable those with a hereditary predisposition for the colorectal cancer to take preventive measures. Applying evidence-based prevention strategies reduces the prognosis of colorectal cancer and reduces mortality. Colorectal cancer has an increased survival rate if diagnosed early and treated properly.
\end{abstract}

Keywords: colorectal cancer, non-modifiable risk factors, modifiable risk factors, screening

\section{REZUMAT}

Incidența cancerului colorectal este în creștere, în prezent este al treilea cel mai frecvent cancer, după cel pulmonar și mamar. Progresele recente realizate în diagnosticul timpuriu, efectuarea screening-ului în conformitate cu recomandările și opțiunile de tratament au redus mortalitatea cancerului colorectal. Rolul medicului de familie constă în consilierea, identificarea factorilor de risc nemodificabili (vârsta, sexul masculin, rasa, ereditatea, bolile inflamatorii intestinale) și modificabili (consumul de tutun, dieta săracă în fibre și bogată în grăsimi și carbohidrați, sedentarismul, obezitatea), evitarea acestora, realizarea unui plan personalizat de prevenție și depistare precoce a cancerului colorectal în funcție de riscul individual. Testarea genetică și o anamneză țintită pot permite celor cu predispoziție ereditară pentru cancer colorectal să 
beneficieze de măsurile preventive. Aplicarea unor strategii de prevenție bazate pe dovezi reduc îmbunătățesc prognosticul cancerului colorectal și reduc mortalitatea. Cancerul colorectal are o rată de vindecare crescută dacă este diagnosticat precoce și tratat adecvat.

Cuvinte cheie: cancer colorectal, factori de risc nemodificabili, factori de risc modificabili, screening

\section{EPIDEMIOLOGIE}

Incidența bolilor neoplazice și mortalitatea cauzată de acestea au crescut rapid la nivel mondial. Acest lucru reflectă atât îmbătrânirea populației, cât mai ales schimbările în prevalența și distribuția principalilor factori de risc modificabili pentru cancer, de la stil de viață sedentar, dietă bogată în grăsimi și carne procesată. Globocan apreciază pentru anul 2020 apariția a peste 1,9 milioane de cazuri noi de cancer colorectal, locul trei după cancerul de sân și pulmonar și peste 935.000 de decese datorate cancerul colorectal, locul al doilea ca mortalitate după cancerul pulmonar $[1,2]$.

Cancerul colorectal poate fi considerat un marker al dezvoltării socioeconomic. În țările aflate în curs de dezvoltare, ratele de incidență tind să crească paralel cu creșterea HDI (human development index, instrument de măsurare a speranței de viață fără dizabilități, a nivelului educational al populației și a produsului intern brut) [2-4]. La bărbați, primele trei tipuri de cancer cu cea mai mare incidență sunt cancerul pulmonar, de prostată și colorectal, cancerul pulmonar fiind și principala cauză de deces, urmat de cancerul de ficat și colorectal [4]. La femei, cel mai frecvent tip de cancer diagnosticat este cancerul de sân, urmat de cancerul colorectal. Morbiditatea prin cancer colorectal la femei reprezintă cea de-a treia cauză după cancerul de sân și cel pulmonar [4].

În ultimul deceniu, s-a înregistrat o scădere a mortalității prin cancer colorectal prin stabilirea diagnosticului în stadiile incipiente, progresele înregistrate în schema de tratament și procedurile terapeutice, chiar dacă incidența cancerului colorectal a crescut [5]. La scăderea mortalității a contribuit și intensificarea utilizării metodelor de diagnostic precoce la persoanele cu factori de risc. Introducerea unor teste de screening mai performante poate să determine inițial rate de incidență crescute datorită diagnosticului precoce, dar, pe termen lung, va reduce mortalitatea ca urmare a îndepărtării polipilor precanceroși sau în stadii inițiale de dezvoltare [6].

Consilierea, identificarea factorilor de risc modificabili (consumul de tutun, dieta săracă în fibre și bogată în grăsimi și carbohidrați, sedentarismul, obezitatea), evitarea acestora precum și aplicarea unor strategii de prevenție bazate pe dovezi pot preveni 30-50\% dintre cazurile de cancer în general [7]. Cancerul colorectal are o rată de vindecare crescută dacă este diagnosticat precoce și tratat adecvat [8].

Strategia de screening pentru cancerul colorectal (CCR) depinde de prezența sau absența factorilor de risc [7].

Dezvoltarea cercetării evoluției cancerului colorectal, a factorilor de risc nemodificabili și modificabili, prezentați succint în tabelul 1, poate aduce o contribuție esențială la prevenirea și tratarea cancerului colorectal [9].

\section{FACTORI DE RISC NEMODIFICABILI}

Incidența și mortalitatea cancerului colorectal variază în funcție de sex, rasă și etnie [10]. Conform raportului $C D C$, bărbații și femeile afro-americane au rate de incidență și mortalitate mai mari decât bărbații și femelele caucaziene, indieni americani, nativi din Alaska și asiatici. Bărbații și femeile care nu sunt hispanici au rate de incidență și mortalitate mai mari decât bărbații și femeile hispanice. Pacienții afro-americani și din medii socio-economice defavorizate, precum și persoanele în vârstă sunt mai predispuși să prezinte tumori avansate la momentul diagnosticului [11]. Proporția cancerelor colorectale diagnosticate înainte de vârsta de 50 de ani este aproape de două ori mai mare la asiatici, rasa neagră și latino-americani decât la rasa albă, conform unui studiu care a analizat datele din Registrul de cancer din California [12]. Independent de vârstă și de etnie, bărbații au un risc de 1,5 ori mai mare de a dezvolta CCR decât femeile [13]. În comparație cu bărbații, femeile sunt mai predispuse la cancerul de colon ascendent, care este asimptomatic în fazele inițiale, fiind asociat cu o formă mai agresivă de neoplazie în comparație cu cancerul de colon descendent [14]. Întrun sistem medical având acces egal, vârsta tânără la prezentare ( $<50$ de ani) a fost asociată cu un stadiu mai avansat și cu recurența mai mare a cancerului colorectal [15]. În era screeningului CCR, incidența ajustată în funcție de vârstă a CCR la bărbați este semnificativ mai mare decât la femei [16].

CCR ereditare reprezintă 7-10\% dintre toate cazurile și includ sindromul cancerului colorectal nonpolipozic ereditar și sindroamele polipozice adenomatoase (polipoza adenomatoasă familială PAF și polipoza asociată MUTYH) și hamartomatoame (sindrom Peutz-Jeghers, polipoza juvenilă, polipoza asociată ADN-polimerazei) [17]. Principalele CCR ereditare, genele implicate și mo- 
dalitatea de transmitere sunt reprezentate în tabelul 2. Sindromul Lynch predispune la neoplazii extracolonice, precum cele endometriale, gastrice, ovariene, intestinale, ale epiteliului hepatobiliar, epiteliului urotelial și neoplasmul cerebral [18]. Evaluarea riscului genetic în vederea diagnosticului de sindromul cancerului colorectal nonpolipozic ereditar se realizează prin evidențierea antecedentelor familiale de neoplazie colonică, determinarea existenței altor cancere care pot fi întâlnite în cadrul acestui sindrom, descoperirea unui istoric familial tipic, cu cancere sincrone și metacrone, stabilirea vârstei instalării acestor cancere $[9,17]$.

TABEL 1. Factorii de risc pentru cancerul colorectal

\begin{tabular}{|c|c|c|}
\hline 1 & $\begin{array}{l}\text { Factori de risc } \\
\text { nemodificabili }\end{array}$ & $\begin{array}{l}\text { Rasa } \\
\text { Etnicitatea } \\
\text { Vârsta } \\
\text { Sexul masculin } \\
\text { Ereditatea } \\
\text { Bolile inflamatorii intestinale } \\
\text { Radioterapie abdominopelvină } \\
\text { Fibroză chistică }\end{array}$ \\
\hline 2 & $\begin{array}{l}\text { Factori de risc } \\
\text { modificabili }\end{array}$ & $\begin{array}{l}\text { Dieta } \\
\text { Obezitatea } \\
\text { Sedentarismul } \\
\text { Fumat } \\
\text { Consum de băuturi alcoolice }\end{array}$ \\
\hline
\end{tabular}

TABEL 2. Principalele cancere colorectale ereditare, genele implicate și modalitatea de transmitere - adaptat după [9]

\begin{tabular}{|c|c|c|c|}
\hline & Condiția & Genele implicate & Transmiterea \\
\hline 1 & $\begin{array}{l}\text { Sindromul } \\
\text { cancerului colorectal } \\
\text { non-polipozic } \\
\text { ereditar - sindrom } \\
\text { Lynch }\end{array}$ & $\begin{array}{l}\text { MLH1, MSH2, } \\
\text { MSH6, EpCAM, } \\
\text { PMS2 }\end{array}$ & $\begin{array}{l}\text { Autozomal } \\
\text { dominant }\end{array}$ \\
\hline 2 & $\begin{array}{l}\text { Polipoza } \\
\text { adenomatoasă } \\
\text { familială (PAF) }\end{array}$ & APC & $\begin{array}{l}\text { Autozomal } \\
\text { dominant }\end{array}$ \\
\hline 3 & $\begin{array}{l}\text { Sindrom Gardner } \\
\text { (variantă a PAF) }\end{array}$ & APC & $\begin{array}{l}\text { Autozomal } \\
\text { dominant }\end{array}$ \\
\hline 4 & $\begin{array}{l}\text { Sindrom Turcot } \\
\text { (variantă a PAF) }\end{array}$ & APC, MLH1, PMS2 & $\begin{array}{l}\text { Autozomal } \\
\text { dominant/ } \\
\text { recesiv }\end{array}$ \\
\hline 5 & $\begin{array}{l}\text { Polipoza asociată } \\
\text { MUTYH }\end{array}$ & MUTYH, APC & $\begin{array}{l}\text { Autozomal } \\
\text { recesiv }\end{array}$ \\
\hline 6 & Polipoza juvenilă & $\begin{array}{l}\text { SMAD4(MADH4), } \\
\text { BMPR1A(ALK3) }\end{array}$ & $\begin{array}{l}\text { Autozomal } \\
\text { dominant }\end{array}$ \\
\hline 7 & $\begin{array}{l}\text { Sindrom Peutz- } \\
\text { Jeghers }\end{array}$ & STK11(LKB1) & $\begin{array}{l}\text { Autozomal } \\
\text { dominant }\end{array}$ \\
\hline 8 & $\begin{array}{l}\text { Polipoza asociată } \\
\text { ADN-polimerazei }\end{array}$ & POLE, POLD1 & $\begin{array}{l}\text { Autozomal } \\
\text { dominant }\end{array}$ \\
\hline 9 & $\begin{array}{l}\text { Sindromul de } \\
\text { hamartomatoză } \\
\text { asociată PTEN } \\
\text { (sindrom Cowden) }\end{array}$ & PTEN & $\begin{array}{l}\text { Autozomal } \\
\text { dominant }\end{array}$ \\
\hline 10 & $\begin{array}{l}\text { Sindromul X în } \\
\text { cancerul colorectal } \\
\text { familial }\end{array}$ & $\begin{array}{l}\text { BRCA2, KRAS, } \\
\text { APC, NTS, BRAF, } \\
\text { BMPR1A, RPS20 }\end{array}$ & $\begin{array}{l}\text { Autozomal } \\
\text { dominant }\end{array}$ \\
\hline 11 & $\begin{array}{l}\text { Sindromul polipozei } \\
\text { NTHL1 }\end{array}$ & NTHL1 & $\begin{array}{l}\text { Autozomal } \\
\text { recesiv }\end{array}$ \\
\hline
\end{tabular}

Pacienții cu boala inflamatorie intestinală (două entități: colita ulcerativă și boala (rohn) prezintă un risc dublu de a dezvolta CCR [9]. Factorii determinanți primari implicați în apariția CCR sunt durata bolii, gradul de afectare colonică și activitatea bolii. Pancolita determină o creștere de 5-15 ori a riscului de CCR în comparație cu incidența estimată în populația generală, în timp ce prezența unei colitei ulcerative limitată la colonul descendent este asociată cu un risc de apariție a cancerului de trei ori. Dacă boala este limitată la nivelul rectului sau sigmoidului, riscul nu crește semnificativ $[19,20]$. Alți factorii implicați în creșterea incidenței cancerului colorectal la pacienții cu boală inflamatorie intestinală sunt reprezentați de istoric familial de cancer colorectal, prezența colangeitei sclerozante, debut al bolii inflamatorii la vârstă mică [21].

Pancolita datorată bolii Crohn se asociază cu un risc similar de apariție a cancerului colorectal ca și în cazul colitei ulcerative extinse. Majoritatea ghidurilor recomandă monitorizarea activă atunci când este afectată cel puțin o treime din mucoasa colonică [22].

Riscul crescut de cancer colorectal a fost observat și la copiii și adolescenții care au necesitat radioterapie abdominopelvină în copilărie pentru diferite afecțiuni maligne [23]. Bărbații diagnosticați cu cancer de prostată au prezentat un risc crescut de diagnostic ulterior de cancer colorectal $[23,24]$. Radioterapia folosită în cancerul de prostată a fost asociată cu un risc crescut de cancer rectal [24].

Pacienții cu fibroză chistică au un risc crescut de CCR [25]. Într-o metaanaliză efectuată de către Yamada et al., care a analizat șase studii de cohortă, ce au inclus peste 90.000 de pacienți, a arătat că riscul de CCR a fost de 10 ori mai mare la pacienții cu fibroză chistică [26]. Fundația pentru fibroză chistică recomandă introducerea pacienților cu fibroză chistică în screeningul CCR pentru adulți [25].

Colecistectomia este asociată cu un risc crescut de cancer de colon ascendent, mecanismul posibil implicat fiind reprezentat de expunerea intestinală la conținutul biliar [26]. Un studiu publicat de Chen et al. care a evaluat riscul de CCR la un lot de peste 83.000 de pacienți din Taiwan a arătat că asocierea pozitivă dintre colecistectomie și riscul de CCR în primele 6 luni după colecistectomie s-ar putea datora lipsei de diagnostic a unui cancer preexistent, riscul de apariție a unui CCR scade după 6 luni de la intervenția chirurgicală [27].

La pacienții cu cancer de prostată, care sunt supuși terapiei de deprivare a androgenilor cu agoniști ai hormonului de eliberare a gonadotropinei $(\mathrm{GnRH})$ sau orhiectomie, există un risc crescut de CRC [28]. Studiile sugerează că riscul de cancer colorectal și de prostată este crescut în rândul celor cu antecedente familiale pentru cele două tipuri de cancere, în special în rândul rudelor de gradul I. Cu toate acestea, agregarea cance- 
rului colorectal și de prostată în cadrul aceleiași familii necesită studii care să investigeze relația bidirecțională dintre cele două afecțiuni [29].

Studiile raportate sugerează că adenoamele colonului și CCR apar cu frecvență crescută în acromegalie, în special la cei cu boală necontrolată [30].

\section{FACTORI DE RISC MODIFICABILI}

Dieta reprezintă unul dintre factorii de risc modificabili cei mai implicați în apariția CCR. Dieta poate avea rol protector sau poate crește riscul de apariție a CCR, indiferent de asocierea cu sedentarismul sau obezitatea. Dieta are un impact semnificativ asupra microbiomului și gradului de inflamație a colonului [31]. Un studiu efectuat de către Surya subliniază faptul că mecanismul de favorizare a apariției CCR datorat consumului de carne roșie are la bază efectele fierului existent, proprietăți cancerigene sunt independente de metoda de gătit [32]. Prelucrarea cărnii roșii la temperaturi ridicate poate produce, de asemenea molecule cancerigene nou formate precum amine heterociclice și hidrocarburi poliaromatice care sunt asociate pozitiv cu cancerul colorectal. Eliminarea totală a cărnii roșii din dietă nu ar fi soluția pentru a reduce incidența CCR într-o populație, deoarece carnea roșie are și alte efecte nutriționale benefice pentru oameni. Se recomandă limitarea consumului săptămânal individual de carne roșie la cel mult 500 g [32]. Unele studii sugerează că asocierea dintre consumul de carne procesată și riscul de CCR este influențată de ereditate [33].

Studiile arată că administrarea suplimentelor cu calciu, fibre, vitamina $D$, precum și fructe și legume au un efect protector împotriva CRC [9]. Suplimentarea cu folat pare să inhibe carcinogeneza, dar favorizează dezvoltarea tumorilor existente [9]. Fibrele care se găsesc în mod obișnuit în fructe, legume și cereale integrale au efect protector, prin promovarea tranzitului intestinal, și reducerea expunerii la potențiali agenți cancerigeni [34].

Atât obezitatea, cât și sedentarismul reprezintă factori de risc modificabili cu impact semnificativ la dezvoltarea CCR [9]. Studiile au constatat că cei care sunt activi fizic în mod regulat au șanse cu $25 \%$ mai mici de a dezvolta CCR9. De remarcat, relația între lipsa activității fizice și riscul de până la $50 \%$ de a dezvolta CCR. Sedentarismul are ca rezultat obezitatea, care poate modifica microflora intestinală și determină inflamația epiteliul intestinului gros, favorizând astfel carcinogeneza $[9,31]$.

Stdiile arată că bărbații cu obezitate prezintă un risc cu 50\% mai mare de cancer de colon și cu $20 \%$ un risc mai mare de cancer rectal comparativ cu femeile, respectiv $20 \%$ pentru cancer de colon și $10 \%$ cancer rectal. Obezitatea și sedendarismul sunt factori de risc independenți pentru CCR. O metaanaliză a 13 studii de cohortă a arătat că o creștere în greutate de $5 \mathrm{~kg}$ a fost asociată cu un risc cu $3 \%$ mai mare de CRC [35]. Grăsimea viscerală este implicată în dezvoltarea CCR, prin urmare, atât circumferința abdominală, cât și IMC sunt intrumesnte clinice utilizate pentru a evalua riscul crescut de CCR în practica medicului de familie. Obezitatea și sedentarismul nu numai că predispun la rate mai mari de incidență, dar sunt asociate și cu o mortalitate crescută prin CCR [36]. Riscul excesiv asociat cu obezitatea este redus după scăderea ponderală, fie prin intervenția cumulată prin dietă și activitate fizică, fie prin intervenția chirurgicală bariatrică. Se estimează că ratele de CCR se apropie de cele din populația generală în termen de cinci - șase ani de la normalizarea și menținerea greutății [37].

O metaanaliză efectuată de Shaw et al. a arătat un risc relativ mai mic de apariție a cancerului colorectal la pacienții cu indice de masă corporală mai mare, sugerând un beneficiu suplimentar al activității fizice ca strategie de preveniție a CCR în grupurile de populație cu factori de risc pentru cancerul colorectal [38]. Studiile observaționale și experimentale efectuate în ultimii ani privind relația între activitatea fizică și riscul de apariție a CCR, precum și ratele de vindecare sugerează că exercițiile fizice pot modifica biologia CRC prin mecanisme diferite: modificări ale metabolismului glucidic (insulină, IGF), modificări ale adipokinelor (leptină și adiponectină), stres oxidativ, inflamație și afectarea funcției imune, precum și prin mecanisme epigenetice (metilare ARN, ADN) $[39,40]$. Intervențiile asupra stilului de viață, modificarea dietei și intensificarea exercițiilor fizice sunt recomandate ca metodă eficientă de prevenire a CRC și de îmbunătățire a efectelor negative ale cancerului și ale tratamentului acestuia, chiar dacă nivelul de activitate fizică necesar, tipul și intensitatea exercițiului sunt încă neclare [40].

În cea mai mare parte, risc crescut de apariție a diferitelor tipuri de cancer la pacienții cu diabet zaharat tip 2 se datorează factorilor de risc comun, cum ar fi obezitatea și stilul de viață sedentar [9]. De asemenea, nivelul crescut al glicemiei la pacienții cu diabet zaharat determină glicoliză cu efect carcinogen (așa numitul efect Warburg) prin accelerarea metabolismului glucozei $[9,40]$. Cu toate acestea, cei cu diabet de tip 2 au un risc crescut de CCR chiar și după ajustarea pentru indicele de masă corporală (IMC), activitate fizică și alți factori comuni [9]. O metaanaliză a 29 de studii prospective de cohortă (peste 62.000 cazuri) în China a raportat un risc cu $27 \%$ mai mare de CRC asociat cu diabetul [41].

Consumul moderat crescut de băuturi alcoolice (mai mult de o unitate alcool pe zi $=10 \mathrm{~g}$ alcool pur) este asociat cu un risc crescut de CCR $[9,42,43]$. Persoanele care consumă 2-3 unități pe zi au un risc crescut de 
$20 \%$ de a dezvolta CRC, în timp ce pentru cei peste trei unități, acest risc crește la 40\% [42,43]. Mecanismul implicat nu este încă pe deplin cunoscut, se presupune efectul alcoolului că antifolat și rolul alcoolului în metabolismul metioninei, cu rol în carcinogeneză; asocierea este mai puternică la bărbați, fiind implicat și efectul hormonal în metabolismul alcoolului $[9,21]$.

Fumatul este considerat factor de risc și pentru CCR. Atât pentru incidență, cât și pentru mortalitate, asocierea între fumat și CCR a fost mai puternică pentru cancerul de rect comparativ cu localizarea cancerului în celelalte segmente ale colonului $[9,21]$. Consumul de tutun este asociat cu prognostic defavorabil pentru CCR comparativ cu cei care nu au fumat niciodată. Oprirea fumatului a fost asociată cu îmbunătățirea supraviețuirii generale și specifice CRC [44]. De menționat faptul că fumatul poate crește riscul de CCR la pacienții cu sindrom Lynch [45].

A fost studiat rolul protector al unor medicamente, precum antiinflamatoarelor nesteroidiene, bifosfonații orali, inhibitorii enzimei de conversie a angiotensinei, statine [46-49].

Referitor la efectul protectiv al antioxidanților, diferitele studii raportate nu au arătat dovezi convingătoare că suplimentele antioxidante au avut un efect benefic semnificativ în prevenția primară sau secundară a adenoamelor colorectale [50].

Efectele protectoare ale utilizării terapiei hormonale de substituție la menopauză rămân controversate. În timp ce studiile observaționale par să găsească un risc scăzut de CCR, studiile randomizate pe termen lung nu susuțin efectul protectiv. De asemenea, contraceptivele orale s-au crezut odată că scad riscul de CRC, deși studiile actuale nu au găsit dovezi în sprijinul acestei afirmații [51]. Urmărirea pe termen mai lung a confirmat faptul că prezența CCR la femeile care au primit terapie hormonală combinată au fost asociate cu o rată a mortalității semnificativ mai mare. Acest lucru sugerează fie un diagnostic tardiv al CCR fie influența terapiei hormonale de substituție asupra biologiei CCR [52].

\section{INTERVENȚIA MEDICULUI DE FAMILIE}

Medicul de familie are un rol important atât în prevenția primară, cât și în prevenția secundară a CCR. Medicul de familie intervine prin consiliere, promovarea sănătății mai ales pentru acei pacienții care prezintă factori de risc nemodificabili pentru CCR. Cunoașterea și identificarea acestor factori reprezintă prima etapă în promovarea sănătății. Cu ocazia examenelor de bilanț, medicul de familie identifică pacienții cu risc pentru apariția CCR, informează despre prezența riscului, întocmește un plan de prevenție personalizată. De asemenea, medicul de familie informează pacientul despre posibilitatea efectuării screeningului și programea- ză pacientul în vederea efectuării testelor de screening conform cu recomandările și riscul individual al pacientului. Metodele folosite pentru screeningul CCR sunt reprezentate de metode neinvazive (mai ușor acceptate de către pacient) și de metode invazive (mai greu acceptate de către pacient, necesită o pregătire specială).

Metodele neinvazive sunt reprezentate de testarea imunohistochimică fecală (FIT - fecal immunochemical test) sau testul Hemocult (high-sensitivity guaiac based fecal occult blood test - FOBT), recomandat anual; ADN-ul fecal, recomandat la 3 ani; colonografia CT (colonoscopie virtuală folosind raze $\mathrm{X}$ ), recomandată la 5 ani; capsula endoscopică colonică (cu indicație pentru vizualizarea colonului proximal la pacienții cu o colonoscopie anterioară incompletă sau pentru cei la care colonoscopia nu se poate efectua), recomandată la 5 ani. Metode invazive sunt colonoscopia (la10 ani) și sigmoidoscopia (la 5 ani sau 10 ani) [53].

American Cancer Society recomandă, începând din 2019, ca vârsta de început a screeningului să fie de 45 de ani, pentru toți indivizii care au o rată medie de risc [54].

Persoanele cu risc crescut, prin istoric personal sau familial de cancer colorectal, boală inflamatorie intestinală, expunere la radiații la nivel abdominal în antecedente sau alți factori care cresc riscul de cancer colorectal, ar trebui să înceapă screeningul mai devreme de 45 de ani și să fie supuși screeningului de preferat prin colonoscopie, la 3-5 ani [53,54].

Un mod practic de a determina riscul este bazat pe trei întrebări adresate pacientului [54,55]: Ai o rudă de gradul întâi cu CCR sau sindrom Lynch diagnosticat înaintea vârstei de 50 de ani? Ai avut CCR sau polipi colonici diagnosticați înainte de 50 de ani? Ai trei sau mai multe rude cu CCR?

Orice răspuns „da” la cel puțin o întrebare este considerat a fi de risc înalt pentru CCR.

Medicul de familie evaleuază fiecăre persoană între 45 și 49 de ani în vederea identificării factorilor de risc (sex masculin, IMC mare, istoric familial, statusul de fumător actual sau în trecut, boli inflamatorii intestinale sau răspuns $\mathrm{cu}$ „da” la una dintre cele trei întrebări amintite). În urma evaluării, medicul de familie stabilește riscul individual și recomandă amânarea screeningului până la vârsta de 50 de ani, dacă nu există factori de risc; recomandă screening neinvaziv pentru prezența a unui sau a doi factori de risc; recomandă screening invaziv pentru prezența a cel puțin trei factori de risc $[54,55]$.

\section{CONCLUZII}

Studiile publicate arată că detecția precoce a cancerului colorectal cu ajutorul screeningului îmbunătățește 
substanțial calitatea vieții și supraviețuirea. Screeningul pentru CCR are și rol preventiv, prin identificarea leziunile precanceroase cu risc înalt de CCR în stadii precoce, curabile. Medicul de familie are un rol important atât în prevenția primară, cât și în prevenția secundară a CCR. Cunoașterea și identificarea factorilor de risc pentru CCR reprezintă prima etapă în promovarea sănătății. Cu ocazia examenelor de bilanț, medicul de familie identifică pacienții cu risc pentru apariția CCR, informează despre prezența riscului, informează despre posibilitatea efectuării screeningului și programează pacientul în vederea efectuării testelor de screening conform riscului individual.

Conflict of interest: none declared Financial support: none declared

\section{BIBLIOGRAFIE}

1. Ferlay J, Ervik M, Lam F, et al. Global Cancer Observatory: Cancer Today. International Agency for Research on Cancer; 2020.

2. Bray F. Transitions in human development and the global cancer burden. In: Stewart BW, Wild CP (eds.). World Cancer Report 2014. WHO Press; 2014:42-55.

3. Fidler MM, Soerjomataram I, Bray F. A global view on cancer incidence and national levels of the Human Development Index. Int J Cancer. 2016;139:2436- 2446.

4. Sung H, Ferlay J, Siegel RL, Laversanne M, Soerjomataram I, Jemal A, Bray F. Global Cancer Statistics 2020: GLOBOCAN Estimates of Incidence and Mortality Worldwide for 36 Cancers in 185 Countries. CA Cancer J Clin. 2021 May;71(3):209-249.

5. Edwards BK, Ward E, Kohler BA, et al. Annual report to the nation on the status of cancer, 1975-2006, featuring colorectal cancer trends and impact of interventions (risk factors, screening, and treatment) to reduce future rates. Cancer. 2010; 116:544-73.

6. Arnold M, Sierra MS, Laversanne M, et al. Global patterns and trends in colorectal cancer incidence and mortality. Gut. 2017;66:683-91.

7. Diaconu C. Screeningul cancerului: categorii la risc, beneficii și limite - capitol în Antropologia Milenului III - Colecția Zilele Rainer, coordonatori Andrei Kozma, Octavian Buda, Constantin BălăceanuStolnici. Editura Academiei Române, 2020.

8. Kyriacou DN. Evidence-based medical decision making: deductive versus inductive logical thinking. Acad Emerg Med. 2004;11(6):670-1.

9. Rawla P, Sunkara T, Barsouk A. Epidemiology of colorectal cancer: incidence, mortality, survival, and risk factors. Prz Gastroenterol. 2019; 14(2):89-103.

10. https://www.cdc.gov/cancer/uscs/about/ data-briefs/no16-colorectalcancer-2007-2016.htm

11. Askari A, Nachiappan S, Currie A, Latchford $A$, et al. The relationship between ethnicity, social deprivation and late presentation of colorectal cancer. Cancer Epidemiology. 2017:47:88-93.
12. Theuer C, Wagner J, Taylor T, Brewster W, Tran D, McLaren C, Anton-Culver H. Racial and ethnic colorectal cancer patterns affect the cost-effectiveness of colorectal cancer screening in the United States. Alimentary Tract. 2001;120(4):848-856.

13. Bray F, Ferlay J, Soerjomataram I, et al. Global cancer statistics 2018: GLOBOCAN estimates of incidence and mortality worldwide for 36 cancers in 185 countries. CA Cancer J Clin. 2018;68:394-424.

14. Kim SE, Paik HY, Yoon H, et al. Sex- and gender-specific disparities in colorectal cancer risk. World J Gastroenterol. 2015;21:5167-75.

15. Steele SR, Park GE, Johnson EK, Martin MJ, Stojadinovic A, Maykel JA, Causey MW. The impact of age on colorectal cancer incidence, treatment, and outcomes in an equal-access health care system. Dis Colon Rectum. 2014 Mar;57(3):303-10.

16. Gangireddy VGR, Talla S. Gender Disparities in the Incidence of Colorectal Cancer in the Era of Screening Colonoscopy, American Journal of Gastroenterology. 2018;113:S99-S101.

17. Yurgelun MB, Kulke MH, Fuchs CS, et al. Cancer Susceptibility Gene Mutations in Individuals With Colorectal Cancer. J Clin Oncol 2017;35:1086.

18. Duraturo F, Liccardo R, De Rosa M, Izzo P. Genetics, diagnosis and treatment of Lynch syndrome: Old lessons and current challenges. Oncol Lett. 2019 Mar; 17(3):3048-3054.

19. Ekbom A, Helmick C, Zack M, Adami HO. Ulcerative colitis and colorectal cancer. A population-based study. N Engl J Med. 1990;323:1228.

20. 20.Olén O, Erichsen R, Sachs MC, et al. Colorectal cancer in ulcerative colitis: a Scandinavian population-based cohort study. Lancet. 2020;395:123.

21. Pop C. Factorii de risc ai cancerului colorectal. Medicina Internă. 2009(6).

22. Annese V, Beaugerie L, Egan L, et al. European Evidence-based Consensus: Inflammatory Bowel Disease and Malignancies. J Crohns Colitis. 2015;9:945.

23. Rombouts AJM, Hugen N, Elferink MAG, et al. Increased risk for second primary rectal cancer after pelvic radiation therapy. Eur J Cancer. 2020;124:142.

24. Desautels D, Czaykowski P, Nugent Z, et al. Risk of colorectal cancer after the diagnosis of prostate cancer: A population-based study. Cancer. 2016;122:1254.

25. Yamada A, Komaki Y, Komaki F, et al. Risk of gastrointestinal cancers in patients with cystic fibrosis: a systematic review and meta-analysis. Lancet Oncol. 2018;19:758.

26. Lagergren J, Ye W, Ekbom A, authors. Intestinal cancer after cholecystectomy: is bile involved in carcinogenesis? Gastroenterology. 2001;121:542-7.

27. Chen $\mathrm{CH}$, Lin CL, Kao CH. The Effect of Cholecystectomy on the Risk of Colorectal Cancer in Patients with Gallbladder Stones. Cancers (Basel). 2020;12(3):550.

28. Gillessen S, Templeton A, Marra G, et al. Risk of colorectal cancer in men on long-term androgen deprivation therapy for prostate cancer. J Natl Cancer Inst. 2010;102:1760-70.

29. Beebe-Dimmer JL, Yee C, Paskett E, Schwartz AG, Lane D, Palmer NRA, Bock $\mathrm{CH}$, Nassir R, Simon MS. Family history of prostate and colorectal cancer and risk of colorectal cancer in the Women's health initiative. BMC Cancer. 2017 Dec 13;17(1):848.

30. Fukuda I, Hizuka N, Murakami Y, et al. Clinical features and therapeutic outcomes of 65 patients with acromegaly at Tokyo Women's Medical University. Intern Med. 2001;40:987.

31. O'Keefe SJ. Diet, microorganisms and their metabolites, and colon cancer. Nat Rev Gastroenterol Hepatol. 2016;13:691-706.

32. Surya R. Mechanistic Hypotheses on Colorectal Cancer and Red Meat Intake: A Review. IOP Conf. Series: Earth and Environmental Science 426, 2020.

33. Figueiredo JC, Hsu L, Hutter CM, et al. Genome-wide diet-gene interaction analyses for risk of colorectal cancer. PLoS Genet. 2014;10:e1004228.

34. Song M, Garrett WS, Chan AT. Nutrients, foods, and colorectal cancer prevention. Gastroenterology. 2015 May;148(6):124460.e16.

35. Karahalios A, Simpson JA, Baglietto L, et al. Change in weight and waist circumference 
and risk of colorectal cancer: results from the Melbourne Collaborative Cohort Study. BMC Cancer. 2016;16:157.

36. Robsahm TE, Aagnes B, Hjartaker A, et al. Body mass index, physical activity, and colorectal cancer by anatomical subsites: a systematic review and meta-analysis of cohort studies. Eur J Cancer Prev. 2013;22:492-505.

37. Bailly L, Fabre R, Pradier C, lannelli A. Colorectal Cancer Risk Following Bariatric Surgery in a Nationwide Study of French Individuals With Obesity. JAMA Surg 2020;155:395.

38. Shaw E, Farris MS, Stone CR, et al. Effects of physical activity on colorectal cancer risk among family history and body mass index subgroups: a systematic review and meta-analysis. BMC Cancer. 2018;18(1):71.

39. Devin JL, Bolam KA, Jenkins DG, Skinner $T L$. The Influence of Exercise on the Insulin-like Growth Factor Axis in Oncology: Physiological Basis, Current, and Future Perspectives. Cancer Epidemiol Biomarkers Prev. 2016;25:239-249.

40. Oruç Z, Kaplan MA. Effect of exercise on colorectal cancer prevention and treatment. World J Gastrointest Oncol. 2019; 11(5):348-366.

41. Jiang $Y$, Ben $Q$, Shen $H$, et al. Diabetes mellitus and incidence and mortality of colorectal cancer: a systematic review and meta-analysis of cohort studies. Eur J Epidemiol. 2011;26:863-76.

42. Bagnardi V, Rota M, Botteri E, et al. Alcohol consumption and site-specific cancer risk: a comprehensive dose-response metaanalysis. Br J Cancer. 2015;112:580-93.

43. Fedirko V, Tramacere I, Bagnardi V, et al. Alcohol drinking and colorectal cancer risk: an overall and dose-response meta-analysis of published studies. Ann Oncol. 2011;22:1958-72.

44. Ordonez-Mena JM, Walter V, Schottker B, et al. Impact of prediagnostic smoking and smoking cessation on colorectal cancer prognosis: a meta-analysis of individual patient data from cohorts within the CHANCES consortium. Ann Oncol. 2018;29:472-83.

45. Pande M, Lynch PM, Hopper JL, Jenkins MA, Gallinger S, et al. Smoking and colorectal cancer in Lynch syndrome: results from the Colon Cancer Family Registry and the University of Texas M.D. Anderson Cancer Center. Clin Cancer Res. 2010 Feb 15;16(4):1331-9.

46. Rothwell PM, Wilson M, Elwin CE, et al. Long-term effect of aspirin on colorectal cancer incidence and mortality: 20-year follow-up of five randomised trials. Lancet. 2010;376:1741-50.

47. Singh $\mathrm{H}$, Mahmud SM, Turner D, et al. Long-term use of statins and risk of colorectal cancer: a population-based study. Am J Gastroenterol. 2009;104:3015.

48. Thosani N, Thosani SN, Kumar S, et al. Reduced risk of colorectal cancer with use of oral bisphosphonates: a systematic review and meta-analysis. J Clin Oncol. 2013;31:623-30
49. Makar GA, Holmes JH, Yang YX. Angiotensin-converting enzyme inhibitor therapy and colorectal cancer risk. J Natl Cancer Inst. 2014 Feb;106(2):djt374.

50. Bjelakovic G, Nagorni A, Nikolova D, et al. Meta-analysis: antioxidant supplements for primary and secondary prevention of colorectal adenoma. Aliment Pharmacol Ther. 2006;24:281.

51. Hildebrand JS, Jacobs EJ, Campbell PT, et al. Colorectal cancer incidence and postmenopausal hormone use by type, recency, and duration in cancer prevention study II. Cancer Epidemiol Biomarkers Prev. 2009;18:2835-41.

52. Simon MS, Chlebowski RT, WactawskiWende J, et al. Estrogen plus progestin and colorectal cancer incidence and mortality. J Clin Oncol. 2012;30:3983.

53. Rex DK, Boland CR, Dominitz JA, Giardiello FM, et al. Colorectal Cancer Screening: Recommendations for Physicians and Patients from the U.S. Multi-Society Task Force on Colorectal Cancer. Am J Gastroenterol. 2017 Jul;112(7):1016-1030.

54. Boieriu E, Negreanu L. Screeningul cancerului colorectal: ce este nou in 2019? Medichub Media, martie 2019.

55. Imperiale TF, Kahi CJ, Rex DK. Lowering the Starting Age for Colorectal Cancer Screening to 45 Years: Who will come... and Should They? Clinical Gastroenterology and Hepatology. 2018 Oct;16(10):1541-44. 